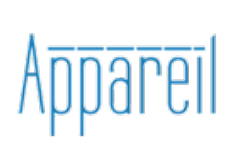

Appareil

4 | 2010

Biopolitique, éthique et subjectivation, questions de modernité

\title{
Rethinking Radical Politics and Ethics
}

Some Badiouian Perspectives by Way of Žižek

\section{Han-yu Huang}

\section{(2) OpenEdition \\ Journals}

Electronic version

URL: https://journals.openedition.org/appareil/904

DOI: 10.4000/appareil.904

ISSN: 2101-0714

Publisher

MSH Paris Nord

\section{Electronic reference}

Han-yu Huang, "Rethinking Radical Politics and Ethics", Appareil [Online], 4 | 2010, Online since 27

January 2010, connection on 12 October 2021. URL: http://journals.openedition.org/appareil/904 ; DOI: https://doi.org/10.4000/appareil.904

This text was automatically generated on 12 October 2021 .

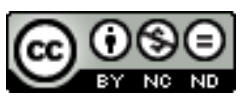

Appareil est mis à disposition selon les termes de la Licence Creative Commons Attribution - Pas d'Utilisation Commerciale - Pas de Modification 4.0 International. 


\title{
Rethinking Radical Politics and Ethics
}

\author{
Some Badiouian Perspectives by Way of Žižek
}

Han-yu Huang

1 As a living exemplification of his own notions of subtraction and universal singularity, Badiou's work as a whole does not fit in any contemporary movement, trend and school of thought (Hallward, Badiou xi; Hewlett 26), the situations with which he actively, critically engages. The multiple, hypertextual relations he establishes with and among other thinkers and writers, be they ancient, modern or postmodern, stand out as a singular case. First of all, his return to the ontological question since time immemorial "how can something new come into being?" brings together theories of the subject, event, being and truth by Plato, St Paul, Pascal, Rousseau, Mallarme, Cantor, Althusser, Lacan, Deleuze, and so on, to a new confrontation of discourses. In many occasions, Badiou explicitly delineates the influences he receives but at the same time is eager to highlight his minimal difference with them. For example, Badiou positions his theory of the subject in relation to, rather than in direct continuity with, Sartre and Lacan, as both contribute to an immanentized, denaturalized notion of the subject: "In my own doctrine, the subject is dependent on an event and only comes to be constituted as a capacity for truth" and is able to dissolve itself into a project that exceeds itself to "attain some subjective real" (Century 100-01). ${ }^{1}$ Some critics, though recognizing Badiou's singular position in contemporary theoretical scene, relegate the multiple relations, influences and differences at issue here to a more or less definite discursive formation. Oliver Marchart coins "post-foundational political thought" to label the set with Schmitt, Ricoeur, Wolin, Rancière, Nancy, Badiou and Mouffe as its members, whose theories, though with different predicates, share the same concerns for the split of politics and the political and the impossibility of the final ground of politics (7). Likewise, Nick Hewlett places Badiou together with Balibar and Rancière within the tradition of emancipatory politics in modern French thought (9-17), which has its counterpart in a more recent renewal of interest in left-oriented thought with a variety of different advocates like Hardt and Negri, Harvey, Jameson, and Žižek (Hewlett 6-7). 
2 If, as presented above, very few can match Badiou's singular intervention in contemporary thought through his multiple relations with other thinkers and theorists regarding the ontological (re)turn to the subject, Truth and radical politics, still fewer stand diametrically against so many philosophical, social, cultural, political and ideological trends as Badiou does. Badiou's subject-oriented thought and faith in the universal Truth-Event mark a radical disagreement with his postmodern French contemporaries like Derrida and Lyotard, whose alignments may be traced back to the linguistic tern, analytic philosophy and hermeneutic tradition, altogether coming down to postmodern cultural, historical relativism and skepticism (Badiou, SP 6). Moreover, Badiou places the derogatory labels like ethical ideology and animal humanism on the turn to (bio)ethics in contemporary French philosophy and Anglo-American cultural criticism, the ethics oriented to the recognition of differences and the Other but victimizing, reducing human to the status of passive, fragile animality (Badiou, $C$ 175, E 10-16, LW 2, SP 6; Hallward, “Translator's Introduction," E xiii). Such ethics for Badiou betrays not only "a symptom of a more general nihilism" (Critchley, Infinitely Demanding 42) but also the false, empty universality as is manifested in capitalist financial globalization and monetary abstraction (SP 6-7). The latter doubles the "fragmentation into closed identities" (SP 10); put in more concrete terms, the assertion and invention of new identities perfectly fits in capitalist logic. In Badiou's own words :

Capital demands a permanent creation of subjective and territorial identities in order for its principle of movement to homogenize its space of action; identities, moreover, that never demand anything but the right to be exposed in the same way as others to the uniform prerogatives of the market. The capitalist logic of the general equivalent and the identitarian and cultural logic of communities or minorities from an articulated whole. (SP 10-11)

3 A critique like this is characterized with Badiou's defense for a singular position against contemporary ethics and identity politics and his denial of any possibility of the authentic universal Truth-Event to them. At this point, we are tempted to ask if Badiou's equation of the capitalist logic with the cultural logic of identity politics implies his conception of the former as impeccable and the latter as hopeless. If contemporary identity politics, cultural, ethnic or national, fails to break with the capitalist logic, can Badiouian politics make it, a politics outside the State, as is emphatically declared throughout his work, and capitalist system too? Do all types of identity politics equally demand to be recognized by the Other and counted in the same way? Or, fundamentally, in what way does Badiou open up for the political subject a Truth-Event beyond the state of contemporary politics and ethics, and in what way does he not turn out to be the object of his critiques?

4 To grapple with the above complications, and to position Badiou's intervention into contemporary thought in general and ethico-political theory in particular, we first need to examine his ontological formulations of the event, truth, and subject. In fact, the title of Badiou's magnum opus, Being and Event, condenses an essential understanding of what are at issue here: namely, an ontological order of Being, of "being-qua-being" with its Other, "what-is-not-being-qua-being." The "and" designates a Two that resists dialectical synthesis (Badiou, C 109). Whereas being belongs to the positivized ontological order of knowledge imposed on the multiplicities of being - hence, the consistent multiplicity of multiplicities - an event brings a new subject and truth into existence: an event, in Badiou's own words, marks a point of rupture at which "the 
ontological field is detotalized or caught in an impasse" (TW 100). However, Badiou cautions us against lapsing into an "obscurantist theory of creation ex nihilo" and equating an event qua a deontoligizing rupture with a miracle: as he accentuates, an event is always localized in particular situations but at the same time is subtracted from the state of situations (the consistent multiplicity of multiplicities). This does not follow that all situations equally allow for an event to happen. Rather, the eventual site - namely, the singular point from which an event happens - must be "on the edge of the void" (BE 175, TW 101), but not vice versa, since the state is always there quick to manipulate, to fill in the void in question. Accordingly, an authentic event, as is hazardous and unpredictable, always constitutes a political, ethical issue. It demands an act of faith (Critchley, Infinitely Demanding 46) and an "interpreting intervention" (the act of naming) from a "subjectively engaged position" (Žižek, The Ticklish Subject 135); 2 it differs from its semblance - in other words, a pseudo-event - in that the latter reinforces rather than undermines, disrupts the status quo. It's exactly such a subjectively engaged act of interpretation and naming that opens up the truth procedure.

5 The subject's act in question here has nothing to do with validating any empirical fact, logical proposition or metaphysical speculation. "Truth" happens to and seizes the subject in the process of being true, namely, fidelity to an event (Badiou, E 42; Critchley, Infinitely Demanding 43). The truth procedure, as well as the event that ignites it, creates an immanent break with the immediate situation and a "minimal, albeit absolute difference... between the place and what takes place in the place, the difference between place and taking-place" (Badiou, $C$ 56). Being thus subjective, subtractive and disruptive, the truth procedure also deviates from the "encyclopedia of knowledge" (Badiou, $E$ lvii) or "the instituted knowledges of the situation" ( $E 43)$ : it resists being allocated to a definite part of the general system of predicative knowledge. In other words, the procedure at stake subtracts truth, its infinite valence, from and in excess of the predicative constructions of language. A truth procedure, in Badiouian terms, presents a pure generic multiple. ${ }^{3}$

6 Badiou's ontological formulations of the event, truth and subject as presented above also apply to his political theory, which subtracts itself from almost all the dominant democratic principles such as representation, consensus, pluralism, and so on, and opposes, on a more empirical level, to contemporary politics of human rights and identity politics as such; identitarian markers like the Aryan, the Jew, the German... for Badiou are all "mystical referential entities" and "the passive body of subjectiviation" (C 103). Put in summarily explicit terms, Badiouian politics, as is singular, momentous and ephemeral, radically intervenes in and prescribes a rupture with what exists ( $M$ 24).

7 A political event, first of all, always takes place in a disruptive relation with the state of the situation, the metastructure that sets a limit on the ontological infinity of the situation and "[exercises] the power of counting over all the subsets of the situation" (M 143). The tension between the situation and the state of situation at issue here doubles the one between the presentation of multiplicities and the representation of consistent multiplicities. And a political event, as a vanishing mediator, clears the ground for imposing a measure to the measureless, excessive and errant superpower of the State, putting it at a distance, and freeing the multiplicities of situation (M 145). Meanwhile, a political event is collective, neither in the sense of numericality - namely, 
not susceptible to counting - nor of any common destiny and monumental history ( $M$ 97), but in a virtual summoning of all subjects as the militants of truth, who resist conceptual, identitarian categorizations (M 142) or who subtract themselves from the system of counting as well. However, all these emancipatory possibilities are yet to be realized by the post-evental truth procedure. Put in Badiou's mathematical terms, the State, as can be seen as a mega-calculator, governs the situation - hence, the consistent multiplicities - by way of organizing the latter's repetitive numerical seriality and, therefore, maintaining the stability and unity of count. In a radical break with all this, a truth procedure does not demand a non-part, an uncounted social member to be counted or a subjugated voice or identity to be recognized as in identity politics as such; such demands, grounded in the principle of difference, will only end up with a complicity with the status quo, the state of situation. In contrast, a truth procedure disrupts the repetition, stability and unity of count and changes the law of counting (Badiou, SP 11); it is only in so doing that radical, authentic equality can be set in motion, "each and every singularity is to be treated collectively and identically," and the Same, rather than Difference, produced (Badiou, M 150). A truth procedure, ultimately, proceeds from setting a measure to the excessive superpower of the State and liberating the infinity of the situation, which Badiou notates as $\pi(\varepsilon)$, to prescribing equality and sameness, $\pi(\pi(\varepsilon) \rightarrow 1$ (M 151-52), "whereby each and every singularity is to be treated collectively and identically" (M 150).

It should be clear by now that the subject relates to truth not as immobile knowledge of contemplation but in the form of intervention and encounter. As Žižek explicates, "Truth is not inherent, it is not the (re)discovery of what is already in myself, but an Event, something violently imposed on me from the Outside through a traumatic encounter that shatters the very foundations of my being" (TS 212). And as indicated above, the subject's intervention in the truth procedure, namely, its recognition of a multiple as an event, demands an act of faith, and Badiou, in following Pascal, famously compares this act to wagering, both of which are, in Bensaïd's words, "irreducible to the dogmatic certainties of positive science as well as to the fickle whims of public opinion" (99) and, more fundamentally, subtract the subject from its immersed, embedded life within a community (Bryant 14; Dews 110). Such understanding also pertains to Badiou's reading of St Paul and his followers, who are "subjects without identity" or "non-parts" not attached to any national, ethnic and cultural markers. The Resurrection as a pure Truth-Event for them is neither demonstrable nor falsifiable and, in other words, does not "fall under the remit of knowledge" (Badiou, SP 45); it is affirmed not in the form of witnessing and memory but in terms of subjective disposition: namely, the subject's fidelity. Thus said, however, we should keep in mind that Badiou does not conceptualize the subject exclusively as the subject faithful to the event, as he is well aware of the possibility that an event may lead to reactionary effects ( $E$ lvii). The Badiouian subject never ceases to think, investigate the situation and to actualize the immanent and continuing break from the point of the event (E 67). The fidelity in question, therefore, concerns not only wager but also more or less consistent political, ethical character. This does not have any implication of foolhardy pertinacity but the certainty that "the subjective will can realize... unheard-of possibilities... [and] intimately touches on the real" (C 99). In the last analysis, the subject's encounter with the Real, as well as with the generic (which is subtracted from any trace of embedded particularity), constitutes the ground of Badiou's model of the ethical. 
9 As pointed out above, few in contemporary theoretical scene can singularize their positions through critically maintaining such multiple relations with other thinkers and theorists as Badiou does, and still fewer concepts arouse so many critical responses as the Truth-Event, as is Badiou's antidote to contemporary depoliticized world and functions as the point of the Real that eludes full symbolization but, at the same time, holds together his philosophical system, radical egalitarian politics, and militant ethical-political subjectivity, as well as all those Badiouian signature concepts like the generic, universal singularity, subtraction, fidelity and so on. Critics of Badiou tend to raise the doubt that Badiouian politics of Truth-Event is detached from actual historical, material conditions, fails to account for the "pre-evental" triggers, address compromise, strategy and realism and provide any criteria for ethical, political choice, all owing to his mathematical ontology dominated by the dualistic distinction between the event and situation (Bensaïd 101; Gillespie 180; Hewlett 41; Johnston 15; Laclau 129; Marchart 130). Such criticisms, though not unreasonable, may lose their credibility and even become pointless if they fail to address the split between politics and the political; they may sound like calling for "returning to the basic" and seem to posit objective ontic realities as always already there: fundamental, radical antagonism may be thus downplayed and the status quo (of liberal democracy) remains intact. With a view to a model of the political that aims to break with the politics of status quo, namely, the dominant liberal-democratic, multiculturalist politics and ethics, and to realize radical equality, the problem of Badiou's universalizing project does not lie in subtraction as such - subtraction from the situation, political realism, strategic calculation, "encyclopedia of knowledge," and so on - but in how to radicalize authentic subtractive politics of Truth-Event. In this aspect, Badiou prescribes local struggles subtracted from but against the State with the aim to fix, even subvert the latter in the long run, and Maoist and Bolshevik politics always stay on Badiou's list of model politics. We may be thus tempted to suspect that Badiou is seduced by past great politics and runs the risk of nostalgically blinding himself to the micro-political struggles of the present (Critchley, "On the Ethics" 234).

10 In many aspects other than the one illustrated right above, Badiou's blindness has selfsubtraction as its variation: the exact status of the Truth-Event, to a certain extent, evades Badiou's theoretical edifice, which appears to be a living, albeit somewhat ironic, exemplification of subtraction. To be more specific, an Event, and its gap with the positive order of Being, does not emerge in itself; it demands the subjectively engaged act of naming: in other words, it is a retroactive construct, and its seizure of and effect on the subject - so to speak, the subject's fidelity to a Truth-Event - are thus indistinguishable from ideological interpellation (Žižek, "Psychoanalysis" 244-45, TS

141). Moreover, Badiou elevates Christ's resurrection, which belongs to Christian religion, to the status of the Truth-Event par excellence, while religion, as the prototype of ideology, is not counted in his four realms of the Truth-Event - namely, love, art, science and politics.

11 As illustrated above, Badiou's unknowing or unknowing subtractions of the TruthEvent from his own theoretical edifice, to a great extent, preclude him from realizing the authentic, radical politics and ethics according to his own formulations. The same also holds for his opposition of the Truth-Event to death drive. When Badiou in Saint Paul addresses the entanglement of the Law and the transgressive desire, he sees the latter as a repetitive automatism that is initiated by the former and brings the subject 
to the site of sin and death: in Badiou's own words, "There is transgression when what is prohibited... becomes the object of a desire that lives through itself in the site and place of the subject" (SP 79). And it is through grace, "the capacity of a postevental multiplicity to exceed its own limit" (SP 78), that the subject breaks with the entanglement or vicious circle in question. Thus said, we are tempted to question how exactly the subject is brought from the automatism of desire, which leads to sin and death, to postevental excess, gratuitousness of grace. Does what "lives through itself" in the subject only seek for the prohibited object and transgression? Is it possible that the subject desires what it does not desire or a transgression of all transgressions too, since desire for Badiou works through a repetitive automatism? Do these questions not bring us the psychoanalytic understanding that desire is, and so is the subject, split in itself and in excess of itself?

If we see the opposition of the Truth-Event to the death drive as the weakest in Badiou, such weakness, according to Bosteels, can be overcome by "radically acknowledging the role of the death drive as a missing third term, or a 'vanishing mediator', between Being and Event" (230). The death drive, to a great extent, holds the key to the above questions. The death drive according to psychoanalytic formulations disregards all utilitarian considerations and goes beyond the reality and pleasure principle, persists, lives through in excess of itself and, hence, disrupts the closure, homeostasis of the positive (ontological, epistemological, or communitarian) order. The Badiouian subject, as pointed out above, realizes "unheard-of possibilities" through its fidelity to the event and encounter, touches on the real. To radicalize his ethico-political theory, therefore, Badiou has no reason to evade the ethical dimension of drive and jouissance. In neglecting this dimension, he also misses the fact that the death drive in psychoanalysis designates the excess, rather than privation, of life that persists beyond the corporeal, earthly "cycle of life and death, of generation and corruption" (Žižek, DLC 395). Badiou may need to learn "the ultimate lesson of psychoanalysis", according to Žižek's explication, that "human life is never 'just life': humans are not simply alive, they are possessed by the strange drive to enjoy life to excess, passionately attached to a surplus which sticks out and derails the ordinary run of things" (DLC 395). Does the Christ-Event not perfectly exemplify the psychoanalytic-ethical lesson in question here?

The entanglement of the law and transgressive desire that Badiou addresses, albeit with his failure to conceptualize the spectrality of (in)human life and drive, pertains to contemporary society of enjoyment, and it is at this juncture that we once again see the significance of psychoanalytic ethics, the sole theory that sets out to deliver the subject out of the difficulty of desiring and enslavement by the ferocious superego. Contemporary consumers are offered an excessive array of commodity to choose from. Life styles, sexual pleasures, cultural identities, spiritualities, fantasies however obscene or perverse... all turn out to be the objects for mass transgressive consumption that allegedly leaves behind various forms of psychical repression or old ideological partitions. What drives all this, from psychoanalytic-ethical perspectives, is the imperative to enjoy from the superego, as is the uncanny, obscene double of the prohibitory Law or the Name-of-the-Father. However, in spite all the images of satisfaction, enjoyment always eludes the subject's full grasp and confronts the subject as irreducible, unbearable Otherness: hence, anxiety that suffocates the subject. What really troubles the subject is not so much the overproximity of the Big Brother's panoptical gaze as the prospect of not being exposed to the Other's gaze enough (Žižek, 
"Neighbors" 180). What moral lesson on contemporary society of enjoyment does The Truman Show enact, if not the anxiety in question here? In the end of the film, Truman takes the "heroic" move to leave all the simulated realities, he is still imagining a Beyond, the Other of the Other and, hence, still falls prey to the superego imperatives to enjoy the (non-simulated, real) Thing. The fantasmatic support of his desire, accordingly, remains intact. Besides, when the superego no longer functions as the underside support of the Law but directly takes the form of the explicit, excessive imperative, desire may be derailed or even come to its deadlock. To perceive what is at stake here, we only need to recall Lacan's thesis that "the more one sacrifices to [the superego], the more it demands" (Seminar VII 302). From Lacanian perspectives, the superego's functioning is paradoxical, split in nature: the moral conscience imposes the prohibition "No!" on the subject, while the former's obscene, perverted fantasmatic underside knows all the secrets of the latter's jouissance and commands it to enjoy/ transgress more than it can bear: the subject always ends up feeling guiltier for not enjoying enough. In the last analysis, contemporary capitalist, post-ideological society of enjoyment not only does not liberate desire but castrates the subject more effectively than downright prohibitions and enslaves it in the superego's vicious circle more than ever.

To learn the ultimate psychoanalytic-ethical lesson, namely, to recognize the death drive as the real ground of ethics and politics, we need to think beyond all multiculturalist ideological-ethical falsifications to the extreme of the inhuman, which should not be understood as the outside to the human but as more human than human or the human in excess of itself. What does contemporary multiculturalist, relativist ethical ideology according to Badiou's critique amount to, if not, from psychoanalytic-ethical perspectives, hindering us from completing the authentic, radical ethical act in the way that it turns us away from the Other's or Neighbor-Thing's radically inhuman excess and monstrosity (Žižek, PV 342) and gentrify it with all the ethical imperatives, for example, to respect the Other, to answer the infinite calling from the Other, or, in a typically Butlerian style, to acknowledge our limited knowing, "our shared, inevitable, and partial blindness" (41), our opacity and our failure and to suspend judgment on the other? The radically real ground of ethics and politics from Badiouian perspectives supplemented by the ultimate psychoanalytic-ethical lesson must be sought in the realm of the living dead, of the Agambenian homo sacer, who, no longer covered by the Imaginary and Symbolic in Lacanian sense, embodies "the zero-level neighbor, the neighbor with whom no empathetic relationship is possible" (Žižek, "Neighbor" 161-62), the zero degree of social existence between symbolic and real death (Santner 100; Žižek, TS 156), as the subject is reduced to bare life and deprived of all the human markers, losing all the intersubjective, symbolic bonds.

With above understanding in mind, we will not see anything viciously sarcastic in Žižek's claim that Agambenian homo sacer stands as the ideal bearer of universal human rights (PV 340), as well as of our multiculturalist respect, tolerance and love. For Žižek, human rights humanism elevates human subjects to their sublime essence through victimizing, reducing them to a form of bare life, absolutely passive and dispossessed, awaiting humanitarian intervention and redemption; human(itarian) subjects, in other words, are split in themselves and never freed of their inhuman excess. To a great extent, Žižek's recent turn to the issue of the inhuman in ethics (or ethics of the inhuman?) simply radicalizes his earlier conception of the identification with the symptom or excremental identification, which amounts to "recogniz[ing] in the 
'excess,' in the disruption of the normal way of things, the key offering us access to its true functioning" (SOI 128). Such recognition is equal to Lacanian subjective destitution according to Žižek's formulation:

The disavowed fundamental passivity of my being is structured in the fundamental fantasy which... regulates the way I relate to jouissance. For that precise reason, it is impossible for the subject to assume his fundamental fantasy without undergoing the radical experience of "subjective destitution": in assuming my fundamental fantasy, I take upon myself the passive kernel of my being - the kernel the distance towards which sustains my subjective activity. (PF 116)

The "passive kernel of my being" in question is the subject "subtracted from all form of human individuality or personality" (VT Xv), hence, the subject at its purest, the inhuman excess of humanity, with which no empathetic, symbolic, or intersubjective relationship is possible. All the typically Žižekian moves involved here, in the last analysis, clear the ground for the authentic act to take place, with the violent outcome that disrupts normality, harmony, consensus, or the order of Being.

of course, we should resist taking passivity and subtraction at their surface value as nothing but apathetic, quietist gestures. We must keep in mind that Žižek recent feverish take on "Bartleby politics", on how the refusal to choose turns to a radical gesture of "passive aggression" (PV 342), goes along with his plea for ethico-political violence and terror in rethinking radical politics. Standing diametrically against the multiculturalist, postmodernist ethics and politics, Žižek, once again, carries his earlier notion of "identifying with the symptom" to its more radical possibility: to open up the conditions for an authentic act to happen, we have to directly identify with violence and recognize that true universality, as is embodied by those "non-parts" or inhuman homo sacers, comes into existence in the guise of excessive, irrational violence (PV 282, TS 204). Through a parallaxical view, such violence confronts us with the fundamental antagonism in contemporary post-political, multiculturalist era, in which each and every voice is supposed to be heard, and each and every part counted on condition that some parts are not counted. In other words, Žižekian ethical violence disrupts the rules that govern counting, recognition, "harmony" and "consensus," as well as the parameters of the possible and impossible. This also pertains to the divine violence that preoccupies Žižek in his latest works. In order not to fall prey to obscurantist mystification and divert our attention to an other-worldly unknowable origin, we should have the courage to equate the eruption of divine, ethical violence with the really existing historical events when "those outside the structured social field strike 'blindly', demanding and enacting immediate justice/vengeance" (VT x). The event of ethical violence, or the ethical violence that happens, fundamentally disrupts the status quo. It is in such a moment that the subject - properly speaking, the ethical, revolutionary subject - wagers an absolute subtraction from the world of the living and all social, communitarian, and symbolic markers, proclaims its own death in advance, and loses the ground of its existence. This is also the moment of emancipatory terror ${ }^{4}$ that suspends the functioning of the Law and the subject's enslavement by the superego injunctions to enjoy in contemporary society of enjoyment as critiqued above. The subject thus heroically assumes "the solitude of a sovereign decision... not covered by the big Other" (VT xi).

To recapitulate: to radicalize his ethics and politics of the Truth-event, subtraction, and universal singularity, Badiou needs to engage himself with, as a supplement to his own work, the psychoanalytic-ethical lesson on the death drive. Meanwhile, the task at issue 
not only opposes to contemporary multiculturalist ethics against violence but has to identify itself with violence as well as terror so that subtraction and passivity will not regress into self-marginalizing quietism. Perhaps, Badiou needs to go to the end of his own thought and seriously confront the possibilities of ethical violence and emancipatory terror. Žižekian ethical violence, put in summarily emphatic way, subtracts the subject from the hegemonic ideological field and destroys its positive content; the subject is radically uprooted from its embedded environments (i.e. regime of opinions and force of habits) or the ethics of finitude as critiqued earlier in this paper; it is brought to a state of ontological dispossessedness or inhuman excess as presented above and the traumatic realization that there is no way back, what it is afraid to lose - ecological balance, social harmony, life world, the substance of community or, in one word, the Other - has already been lost (DLC 434), and it must be ready for the worst. Are we?

\section{BIBLIOGRAPHY}

Badiou Alain, Being and Event, Oliver Feltham (trans.), London, Continuum, 2006.

Badiou Alain, The Century, Alberto Toscano (trans.), Cambridge, Polity, 2007.

Badiou Alain, Ethics: An Essay on the Understanding, Peter Hallward (trans.), London, Verso, 2002.

Badiou Alain, Logics of Worlds: Being and Event II, Alberto Toscano (trans.), London, Continuum, 2009.

Badiou Alain, Metapolitics, Jason Barker (trans.), London, Verso, 2005.

Badiou Alain, Saint Paul: The Foundation of Universalism, Ray Braissier (trans.), Stanford, Stanford UP, 2003.

Badiou Alain, Theoretical Writings, Ray Brassier and Alberto Toscano (Ed. and trans.), London, Continuum, 2006.

Bensaïd Daniel, “Alain Badiou and the Miracle of the Event." in Peter Hallward (Ed.), Think again, Alain Badiou and the Future of Philosophy, London, Continuum, 2004, p. 94-105.

Bosteels Bruno, "Badiou without Žižek.” Polygraph, n 17, 2005, p. 221-244.

Bryant Levi R, "Symptomal Knots and Evental Ruptures: Žižek, Badiou, and Discerning the Indiscernible.” International Journal of Žižek Studies, 1.2, 2007, non-paginated, http://

zizekstudies.org/index.php/ijzs/article/view/30/89 Accessed on 20 May 2009.

Butler Judith, Giving an Account of Oneself, New York, Fordham UP, 2005.

Critchley Simon, "On the Ethics of Alain Badiou." In Gabriel Riera (Ed.), Alain Badiou: Philosophy and Its Conditions, Albany, State University of New York Press, 2005, p. 215-236.

Critchley Simon, Infinitely Demanding: Ethics of Commitment, Politics of Resistance, London, Verso, 2007. 
Dews Peter, "States of Grace: The Excess of the Demand in Badiou's Ethics of Truths." in Peter Hallward (Ed.), Think again: Alain Badiou and the Future of Philosophy, London, Continuum, 2004, p. 106-119.

Gillespie Sam, "Giving Form to Its Own Existence: Anxiety and the Subject of Truth." The Praxis of Alain Badiou, Paul Ashton et al. (Eds.), Melbourne, re.press, 2006, p. 180-209.

Hallward Peter, Badiou: A Subject to Truth, Minneapolis, University of Minnesota Press, 2003. Hallward Peter (Ed.), Think Again: Alain Badiou and the Future of Philosophy, London, Continuum, 2004.

Hallward Peter (trans.), "Translator's Introduction." in Alain Badiou, Ethics: An Essay on the Understanding, London, Verso, 2002, p. 7-47.

Hewlett Nick, Badiou, Balibar, Rancière: Rethinking Emancipation, New York, Continuum, 2007.

Johnston Adrian, "The Quick and the Dead: Alain Badiou and the Split Speeds of Transformation." International Journal of Žižek Studies 1.2, 2007, non-paginated. http://zizekstudies.org/index.php/ ijzs/article/view/28/88 Accessed on 20 May 2009.

Lacan Jacques, The Seminar of Jacques Lacan, Book VII: The Ethics of Psychoanalysis 1959-1960, Dennis Porter (trans.), Jacques-Alain Miller (Ed.), New York, Norton, 1992.

Laclau Ernesto, “An Ethics of Militant Engagement." in Peter Hallward (Ed.), Think Again: Alain Badiou and the Future of Philosophy, London, Continuum, 2004, p. 120-137.

Marchart Oliver, Post-Foundational Political Thought: Political Difference in Nancy, Lefort, Badiou and Laclau, Edinburgh, Edinburgh UP, 2007.

Santner Eric L, "Miracles Happen: Benjamin, Rosenzweig, Freud, and the Matter of the Neighbor." in Žižek Slavoj, The Neighbor: Three Inquiries in Political Theology, Chicago, The University of Chicago Press, 2005, p. 76-133.

Žižek Slavoj, In Defense of Lost Causes, London, Verso, 2008.

Žižek Slavoj, “Introduction: Robespierre, or, the 'Divine Violence', of Terror." in Virtue and Terror, London, Verso, 2007, p. 7-39.

Žižek Slavoj, “Neighbors and Other Monsters: A Plea for Ethical Violence." in The Neighbor: Three Inquiries in Political Theology, Chicago, The University of Chicago Press, 2005, p. 134-190.

Žižek Slavoj, The Parallax View, Cambridge (Mass.), The MIT Press, 2006.

Žižek Slavoj, The Plague of Fantasies, London, Verso, 1997.

Žižek Slavoj, "Psychoanalysis in Post-Marxism: The Case of Alain Badiou." in The South Atlantic Quarterly, vol. 97, n² 2, spring 1998, p. 235-261.

Žižek Slavoj, The Sublime Object of Ideology, London, Verso, 1989.

Žižek Slavoj, The Ticklish Subject: The Absent Center of Political Ontology, London, Verso, 1999.

\section{NOTES}

1. My own emphasis, hereafter cited as $C$. The abbreviations of the titles of Badiou's works cited in this paper include BE (Being and Event), E (Ethics), LW (Logics of Worlds), M (Metapolitics), SP (Saint Paul), TW (Theoretical writings). For publications data, see Works Cited. 
2. Here after cited as TS. Other abbreviations of the titles of works by Žižek include DLC (In Defense of Lost Causes), PF (Plague of Fantasies), PV (The Parallax View), SOI (The Sublime Object of Ideology), VT (Virtue and Terror). For publications data, see Works Cited.

3. The generic is one of the quadruple operations of subtraction at issue here. The undecidable pertains to subtraction from the norm or law, the event as unable to be evaluated; the indiscernible is the subject's subtraction from the marking of sexual, national, or ethnic difference; the unnameable designates a singularity that is unable to be singularized with a proper name. For more details, see "On Subtraction," TW 105-20.

4. In this aspect, Žižek gives sufficient credits to Badiou's call for reinventing emancipatory terror today, though he problematizes Badiou's defense of Terror in the French Revolution and the Maoist Cultural Revolution, as both, according to Žižek, foreclose production proper by reducing it to the political battle and come down to nothing but ideological displacement (PV 326, $V T$ xxi-xxii). Such a critical reading also applies to Badiou's recapitulation of terror in his recent Logics of Worlds as "the projection onto the state of a subjective maxim, the egalitarian maxim" (25), as remains confined by formalistic State politics.

\section{ABSTRACTS}

Alain Badiou's coming to the forefront of the academic debates on the ontological status of Being, political subjectivity, universality, and so on, deserves special attention in an age permeated by disillusionment, cynicism, apathy, or "announcements of ending": summarily, the post-political age. This is also an age when "(hyper)connectivity" with and openness to the Other becomes the dominant currency but radical politics and ethics reach their deadlock, if not demise. Drawing on Badiou's conceptions of subtraction, universal singularity, and the subject loyal to the truth procedure, my proposed paper will critically look at whether contemporary multiculturalism and "society of enjoyment" end up at nothing but relativist ideology, victimization of man, false image of satisfaction and transgression, and, hence, submission to the status quo more than ever. The final part will examine the possibility of supplementing Badiou's universalizing project with Žižek's recent conceptualization of the inhuman and ethical violence and reinvigorating ethicopolitically authentic emancipatory thinking.

\section{AUTHOR}

\section{HAN-YU HUANG}

Associate professor, Department of English, National Taiwan Normal

Universitychyhuang@ntnu.edu.tw 